\title{
Research on the Infringement of Citizens' Privacy Rights by Human Flesh Search in China
}

\author{
Meixiang LI \\ School of law, Shandong University of Technology \\ No.266 Xincun West Road, Zhangdian District, Zibo City, Shandong Province, China
}

Corresponding author's email: potato913 [AT] 163.com

\begin{abstract}
Human flesh search, as a special way of information search, has more and more influence on modern people's life and work. On the one hand, human flesh search does have its positive influences. Some public officials have been removed from their positions after human flesh searches led to corruption investigations. But if human flesh search is abused, it is very likely to infringe on citizens' privacy. To resist the negative effects of human flesh search, China must improve relevant legislation, strengthen network supervision and enhance citizens' self-protection awareness.
\end{abstract}

Keywords---- human flesh search, privacy, privacy rights, protection

\section{INTRODUCTION}

Human flesh search sounds creepy - but it's not a literal search for human flesh. "Ren Rou Sou Suo" refers to the collaborative efforts of netizens in identifying a specific individual. It is a search mechanism that thousands of individuals work to find and make public someone's personal information, mostly online. The phenomenon first emerged in China during the millennium. It originated from Mop.com, an interactive entertainment website. Human flesh search has proliferated profusely in China and other countries in recent years. Some say this technique is a way to seek justice and right wrongs. Others fear they represent a serious violation of online privacy. So the widespread use of this "human flesh search engine" has really been a controversial topic. Human flesh search has its justice side. It is a new way of expression of public opinions, which is conducive to netizens' comprehensive understanding of the event, so that netizens can fully enjoy the right to know. It is also an important way for netizens to exercise their rights of social supervision and criticism. But at the same time, we should also pay attention to the violent nature of human flesh search. "People's "unusually high enthusiasm' makes the human flesh search engine phenomenon unique," Xujun Eberlein, a Chinese American author and commentator, told Forbes. "Participants often 'reach out their hands' thoughtlessly, violating people's rights instead of being righteous." Human flesh search has a realistic impact on the lives and spirits of parties involved in cyber incidents. The personal information of the parties is disclosed, such as mobile phone number, home phone number, home address, etc. This kind of influence usually extends from the network world to the real world, resulting in violation of the privacy rights of the parties.

\section{THE ABUSE OF HUMAN FLESH SEARCH IS AN INFRINGEMENT OF CITIZENS' PRIVACY}

The right of privacy is a right to human dignity that citizens' private life and private information are protected according to law from being illegally disturbed, known, collected, used and disclosed by others. As an important civil right, privacy is more and more valued by people in modern society. The right to privacy is enshrined in the constitutions of many countries as a fundamental right of citizens. The characteristic of modern society is that it requires maximum openness and transparency for the government's actions, and maximum legal protection for citizens' privacy. In the information age, the right of privacy is not only a negative right not to be disturbed, but also a positive and active right of control and use, which fully reflects the right holder's control of his privacy. With the development of society, the content of privacy rights show a trend of diversification and expansion. It includes the following three rights: citizens' rights of secret lives, citizens' rights of peaceful lives, and citizens' rights of space privacy. In the human flesh search incident, all the three privacy rights of the parties are likely to be violated. 


\subsection{The abuse of human flesh search may infringe upon citizens' rights of secret lives}

Citizens' right to secrets in private life is an important condition for maintaining personal dignity and personal freedom. In law, the scope of an individual's private secrets is very broad. From the legal point of view, the scope of personal private life secrets is very broad. In principle, any information that private individuals do not want to disclose to the public is private secret information. Such information is legally protected as long as it does not violate the law and public morality. In the human flesh search incident, many netizens collected, uploaded and published the personal information of the parties. Most of the information belongs to the private information of the person concerned. It should be pointed out that some scholars believe that in the case of human flesh search, the parties usually morally reprehensible persons. The disclosure of their personal information on the Internet is to safeguard social justice. And if the disclosed information is illegal, it is not protected by law. For example, if someone commits adultery with another person, this illegal and unethical behavior should be made public and not protected by the right of privacy. In the author's opinion, it is impossible to generalize whether illegal and unethical information should be made public. Private information related to social public interests and public morality should be made public, but immoral behaviors such as adultery need not be disclosed to the public. Even though prostitution and whoring are obviously illegal and the perpetrator should be punished accordingly, the privacy of the perpetrator is still protected by law. It is not necessary to disclose the perpetrator's personal information to the whole society.

\subsection{The abuse of human flesh search may infringe upon citizens' rights of peaceful lives}

Citizens' rights of peaceful lives refer to citizens' rights to be alone in private lives and not to be disturbed by others. Traditionally, infringement on citizens' rights of peaceful lives is to invade the peace of others' lives by means of illegal peeping, surveillance, tracking and harassment. However, with the development of modern science and technology, the methods of infringing on citizens' rights of peaceful lives are also developing and changing, such as telephone harassment, SMS spam messages, E-mail harassment and so on. In many human flesh search incidents, as the personal information of the parties was published online, the harassment of their online and offline life also continued. This kind of human flesh search without rational constraints eventually evolved into the collective behavior of the Internet mobs, which evolved from the Internet criticism into real violence and seriously disturbed the life peace of the parties (even if the parties to the event should be morally condemned).

\subsection{The abuse of human flesh search may infringe upon citizens' rights of space privacy}

The right of space privacy refers to the right that the parties' private space shall not to be peeped, intruded or interfered by others. In traditional sense, the right of space privacy mainly refers to the right that the residences of citizens are inviolable. However, with the development of Internet, space privacy has shifted from a tangible physical space to an invisible electronic space. The means of invading space privacy have also changed, such as invading other people's computer systems and stealing personal network information. In human flesh search incidents, there are often accompanied by infringements of the parties' space privacy. On May 21, 2008, a video with a length of 4 minutes and 40 seconds appeared on You Tube. In the video, a woman in an Internet cafe was talking about her views on the Sichuan Earthquake and the refugees in the disaster area in a disdainful tone, complaining that the mourning day made her unable to play games. Subsequently, a human flesh search was launched for the woman. Netizens found the Internet cafe through her IP address. Subsequently, her QQ number and QQ space were found, and the relevant information stored therein, including her age, blood type, and residence were disclosed. As the QQ password was cracked by netizens, her colleagues' QQ numbers were also found. Within half an hour, her ID number, family members, address, workplace and even the phone Numbers of her parents and brother were all made public.

\section{THE PROTECTION OF CITIZENS' PRIVACY RIGHTS UNDER THE NETWORK ENVIRONMENT}

\subsection{To improve relevant laws and policies}

First of all, China should formulate the "Personal Information Protection Law" to clearly stipulate the collection, storage, processing, utilization and disclosure of personal data, The Act should regulate the procedures to be followed for data collection, the use of data and its security checks, the rights to data, tort relief and criminal liability,etc. The Standing Committee of the National People's Congress has included the personal information protection law in this year's legislative plan.

Second, the self-discipline policy of the Internet industry should be improved. The Internet industry should take self- 
discipline measures to regulate the collection, use and transaction of personal data, so as to protect the right of privacy. The United States first advocated the important principle of protecting citizens' Internet privacy, and has achieved results in many countries. Internet Society of China is one of the most important self-regulatory organization in China. On March 26, 2002, it promulgated Public Pledge of Self-Regulation and Professional Ethics for China Internet Industry. Article 8 of the Convention provides that all Participants should respect the lawful rights and interests of consumers and should not to use the information provided by users for any activity other than those as promised to users, and no technology or any other advantage may be used to infringe upon the lawful rights and interests of the consumers or users. The author believes that in order to provide users with an intuitive platform to understand the privacy protection status of relevant websites, a non-profit independent organization can be established. The organization will review the privacy policy and implementation of network operators who apply for certification. Network operators who have passed the certification will get the corresponding certification mark and can post the certification logo on their website.

\subsection{To strengthen network supervision}

First, the websites should do a good job of "gatekeeper" and maintain the order of the online search platform. As network service providers, the websites should take some necessary and reasonable technical means to filter and eliminate infringement or illegal information and purify the network environment. Once netizens are found to have uncivilized remarks, website managers should delete posts in time, and exhort and warn them by email, QQ and other means. If the netizen still goes his own way, the website can delete his ID or even block his IP address, depriving him of his right to speak. Second, the website should strengthen its role in information selection and public opinion guidance. By setting up relevant topics or issues, the websites attract users to participate in the public event discussions. Through free and enthusiastic online discussions by netizens, the website can integrate different discourses, guide and promote the correct public opinion. Finally, the websites should give users the necessary reminders to prevent the legal risks brought by the users' possible infringement.

\subsection{To strengthen personal information protection awareness}

In modern society, various personal information will inevitably leave traces on the Internet. Few people are as prescient as Google founders Larry Page and Sergey Brin. Apart from inevitable media interviews, they leave almost no information about their personal lives online. Today, when the connection between individuals and the Internet is inevitable, netizens must strengthen their awareness of self-protection. While enjoying information convenience on the Internet, they must establish a sense of self-protection of privacy. If it is not necessary, netizens should try not to publish their own private information on any web page.

\section{ACKNOWLEDGEMENT}

This project was supported by Humanities and Social Sciences projects funded by Shandong University of Technology. (Project No.: 4032)

\section{REFERENCES}

[1]. Dong Jie, "On the Protection of Civil Rights in 'Human Flesh Search' -From the Perspective of the Conflict Between Privacy and Freedom of Speech”, Journal of Yancheng Institute of Technology (Social Science Edition), vol.9, no.4, pp.78-79, 2018.

[2]. Ding Zhaoyue, "Analysis of the Causes of Network Violence Caused by 'Human Flesh Search"”, Journal of News Research, vol.26, no.23, pp.41-43, 2018.

[3]. Chen Tianqi, “On Privacy Protection Law from the Perspective of 'Cyber Manhunt”,, Journal of Harbin University, vol.40, no.7, pp.69-71, 2019.

[4]. Wang Lili, Zhou Xinli, "Research on the Protection of Network Privacy-Thinking from the Cases of Human Flesh Search", Ability and Wisdom, vol.28, no.31, pp.218-219, 2017.

[5]. Han Rubo, "Sins of the Flesh", The World of Chinese, vol.20, no.3, pp. 41-45, 2018.

[6]. Tang Yue, 'Protection of Internet Personal Information in the Age of 'Big Data' — Taking 'Cyber Manhunt' as an 
Example”, Hebei Normal University of Science \& Technology( Social Sciences ), vol.17, no.2, pp.69-74, 2018.

[7]. Zhang Li, "Legal Protection of Internet Privacy Rights under the Background of Big Data", Journal of Heilongjiang Administrative Cadre College of Politics And Law, vol.12, no.4, pp.70-73, 2018.

[8]. Dong Bin, Zheng Linli, “'Human Flesh Search': Cyber Violence or Public Opinion Supervision”, Social Sciences Review, vol.31, no.12, pp.128-132, 2016.

[9]. Qi Peng, Cui Shujie, Wu Yu, "Reflection upon the protection of Personal Information Right in China from the Perspective of 'Human Flesh Search", Journal of Lanzhou University(Social Sciences), vol.44, no.4, pp.161-170, 2016. 